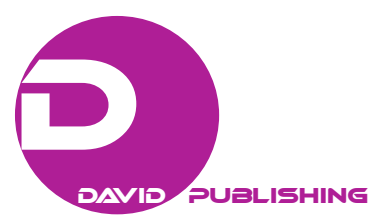

\title{
Measuring the Degree of Innovation in Retail and Services' Micro and Small Enterprises*
}

\author{
Cícero Eduardo Walter \\ Federal Institute of Education, Science and Technology, Piauí, Brazil \\ Cláudia Miranda Veloso \\ University of Aveiro, Aveiro, Portugal \\ Paula Odete Fernandes \\ Polytechnic Institute of Bragança, Bragança, Portugal \\ Humberto Ribeiro \\ University of Aveiro, Aveiro, Portugal
}

\begin{abstract}
Micro and small enterprises (MSEs) are considered the most dynamic and flexible arrangement of activity. In the economy, the foundation and development of these features is important for the creation of the so-called "normal" economic environment. The main objective of this research is to present a research model of innovation in MSEs to analyse: first, the degree of innovation of MSEs, and second, how the innovation is handled by existing MSEs as a result of its business environment. The research made is based on a sample of 550 MSEs distributed over six cities across the Brazilian State of Piauí. The data were collected using the Innovation Radar application, which is owned by the SEBRAE Local Innovation Agents program. Statistical techniques of descriptive, exploratory, and inferential nature were used for corresponding data treatment and results validation. The results obtained suggest that MSEs have innovation capacity between the "Little Innovative" and "Occasional Innovative" range, and also that the average and the distribution of innovation levels are similar amongst MSEs analyzed.
\end{abstract}

Keywords: retail, services, micro and small enterprises (MSEs), innovation management, competitiveness

\section{Introduction}

In the recent past, it was enough for companies to meet their needs in a profitable way to stay in the market, but that scenario has changed dramatically. It is no longer enough simply to meet needs in a profitable way; at present, it is necessary to be one step ahead towards the future, because the strategies that have succeeded in the past are not guarantees of sustainable success, which can be exemplified by Tidd, Bessant, and Pavitt (2008, p. 42) asserting that "organizations build capacities around a particular trajectory, and those that may be strong at a later (specific) stage of an established trajectory find, in general, next".

\footnotetext{
* Acknowledgments: The preparation of the paper was supported by FCT - Portuguese Foundation for the Development of Science and Technology, Ministry of Science, Technology and Higher Education; "Project Code Reference UID/GES/4752/2016".

Cícero Eduardo Walter, Teacher, Federal Institute of Education, Science and Technology. Email: eduardowalter@ifpi.edu.br. Cláudia Miranda Veloso, Teacher, UNIAG; Polytechnic Institute of Bragança; ESTAG; University of Aveiro.

Paula Odete Fernandes, Teacher, UNIAG; NECE; Polytechnic Institute of Bragança.

Humberto Ribeiro, Teacher, ESTAG; GOVCOPP; University of Aveiro.
} 
Accordingly, organizations should seek tools and capabilities to assist them in gaining competitive advantages, which in Martín and López (2007) conception refer to a situation of superiority or favourable conditions that one thing has over another, or as the authors themselves point out, "the concept of competitive advantage is understood as any characteristic of the company that differentiates it from the others, placing it in a relative position of superiority to compete" (p. 267), which Tidd et al. (2008) effectively elected as innovation, although a competitive advantage may arise from size or heritage, among other factors, the scenario gradually shifts in favour of those organizations that continuously manage to mobilize knowledge, what they already have; Information, or what is available in the environment, and the creativity to design the creation of novelties in their offerings, be they products or services, and the ways in which they create and launch these offers.

An innovation according to the Oslo Manual, which is a reference in the subject in several countries, is the implementation of a new or significantly improved product or service, or a process, or a new marketing method, or a new organizational method of the workplace or in external relations (OCDE \& FINEP, 2005).

Innovation is the specific instrument of business activity. It is the action that endows the resources of a new capacity to create wealth. Innovation actually creates the resource. A "resource" is something that does not exist until man discovers a use for something existing in nature and thus endows with economic value (Drucker, 1987).

Ultimately, as Tidd et al. (2008, p. 30) said, "the truth is that, whatever the technological, social or market conditions involved, the key to creating - and maintaining - competitive advantage tends to belong to those organizations that innovate continuously". However, it should be noted that there are significant differences in the way large organizations innovate compared to their smaller counterparts, particularly micro and small enterprises (MSEs). Large organizations may have large resources invested in research and development (R\&D) or market research, which is almost impossible for MSEs due to their financial fragility and the strong competitive pressure from the globalization of markets. While large organizations are apt to develop large-scale innovations, MSEs often adopt innovation strategies through technology acquisition (Tidd et al., 2008).

Given the importance attributed to innovation, the present research has the primary objective of verifying how the innovation presents itself in the MSEs of the State of Piauí, considering that innovation is now considered as the key to obtaining competitive advantages, creating positive results both for the companies involved in the innovation process and for the economy as a whole.

Besides this brief introduction, the article is structured in four points. The following is the framework of the study, where the main concepts that guided the investigation are explained. Subsequently, the conceptual model and the research hypotheses are presented. Next, the analysis of the results is presented, being this the core of the present investigation and, finally, the contributions of the accomplishment of this investigation are presented.

\section{Theoretical Framework}

\section{Concepts of Innovation}

Reichert, Camboim, and Zawislak (2015) postulated that innovation is the result of the capacity of companies, taking into account the technological and market patterns in each branch of activity, of absorbing, adapting and transforming knowledge into technology and this into operational, managerial routines and 
commercial practices that lead companies to achieve superior performance, in keeping with Drucker's (1987) thinking that innovation is an action that provides the resources of a new capacity to create wealth. In the words of Drucker (1987, p. 42), "Innovation creates, in fact, the resource. A resource is something that doesn't exist until man discovers a use for something existing in nature, and thereby endowing it with an economic value".

Schumpeter (1997), considered by some authors (e.g., A. Titu, Raulea, \& S. Titu, 2015; Bayarçelik, Tasel, \& Apak, 2014; Tidd et al., 2008) as a pioneer in innovation studies, stated that innovation would be a spontaneous and discontinuous change in the flow channels, disturbance of equilibrium, which forever changes and shifts the pre-existing state of equilibrium, a new combination of elements in the economic system, a "creative destruction", as the result of this combination would break with the existing standards giving rise to new standards that would be followed by all the economic agents who could adapt to the new circumstances. It is a dynamic process in which new technologies replace old ones.

For OCDE and FINEP (2005), innovation can be understood as the implementation of a new or significantly improved product (product or service), or a process, or a new marketing method, or new organizational business practices, the organization of the workplace or in external relations. The minimum requirement for defining an innovation is that the product, process, marketing method, or organizational are new (or significantly improved) for the company. This includes products, processes and methods that companies are the pioneers to develop and those that have been adopted by other companies or organizations (OCDE \& FINEP, 2005).

\section{Innovation and Competitive Advantage}

The concept of competitive advantage is related to any characteristic of the company that differentiates it from the others, placing it in a position of relative superiority to compete. Martín and López (2007) explained that a competitive advantage must meet three criteria: must be related to a key factor of success in the market, must be substantial enough to give the company a differential and be sustainable in the face of changes in the environment. Although in the long run none is totally free from attacks by competitors.

In today's economy, which is considered to be a knowledge-intensive economy, innovation management is becoming one of the main drivers of change and gaining competitive advantage (Apak \& Atay, 2014).

Thus, given the current competitive conditions in the markets, the only form of competitive advantage is continuous innovation at a faster pace than rival organizations (Toivonen, 2015).

Rusu (2016, pp. 166-167) stated that "successful companies to survive and thrive introduce innovations that generate change within companies by implementing processes that have consequences on their business model enabling profit generation".

It is clear that the company of the present century is operating in an increasingly globalized environment, and that resources and capabilities and innovation should be considered as key elements in the strategy and in the maintenance and development of competitive advantages (Molano \& Campo, 2014). For Seo and Chae (2016, p. 708), "the business world harbours a number of threats and uncertainties requiring a high degree of innovation as a factor of success. A strong degree of innovation can cover several risks when facing the market". 
Specifically, innovation means efforts by companies to create economic value for consumers by positively increasing the difference between the perceived value of consumers and the economic costs incurred by companies. Companies will have a competitive advantage when they can create marginal economic value greater than their competitors. Thus, innovation can be a source of competitive advantage (Hamdani \& Wirawan, 2012).

The competitiveness of a company in the market depends on the ability to "capture the market" using ideas and marketing innovation through business relationships. In this way, the competitiveness of the markets demands of the companies an innovative position, especially in what concerns the marketing (Gupta, Malhotra, Czinkota, \& Foroudi, 2016).

\section{Innovation in MSEs}

Innovation and the development of innovative capabilities in MSEs entails a number of difficulties, as Rovere (2001, p. 22) stated that, "the innovative capacity of MSE depends on several factors related to the organization of the sector and the system of innovations in which they meet". Paula (2014) said that for MSEs, it is possible to notice a greater difficulty in the innovation process, because they have less access to sources of information on technologies and sources of financing, complemented by the lack of resources, few or non-existent investments in $\mathrm{R} \& \mathrm{D}$, strong dependence on technology acquisition (machinery and equipment) and limited managerial capacities (Demonel \& Marx, 2015; Reichert et al., 2015; Taborda, Estevão, \& Nunes, 2013), which leads them to operate with equipment and technologically outdated facilities, carrying out low investment in $\mathrm{R} \& \mathrm{D}$, being slow and reluctant to adopt managerial and organizational innovations (Rodrigues, 2003).

Pereira, Grapeggia, Emmendoerfer, and Três (2009) argued that, even though MSEs have difficulties in assimilating managerial professionalization, precarious levels of control, financial problems such as lack of working capital and incipient knowledge of the market in which they operate, most MSE entrepreneurs associate innovation less with the differentiated elaboration of products and services and more as a business model.

As a result of this context, innovation in MSE presents itself as the result of simple actions, in some cases with its own development, acquisitions of new equipment, adoption of innovation management practices and, usually, incremental innovations, presenting as alternative types of advantages, resulting from attributes such as quality, processes, offer of new products that promote the differentiation of the organization, since they have particularities that are presented as sources of competitive advantage when compared to large companies. They usually have a leaner and more flexible organizational structure, placing them in closer contact with their clients, as well as carrying out activities with low capital intensity and high labour intensity, which can lead to differentiated production conditions (Rodrigues, 2003; Paula, 2014).

\section{Research Methodology}

\section{Conceptual Model}

Figure 1 presents the conceptual research model proposed to evaluate how innovation presents itself in MSEs. The proposed model was developed based on recommendations of the Oslo Manual (OCDE \& FINEP, 2005), considering innovation as a system of interactions and interdependencies. 


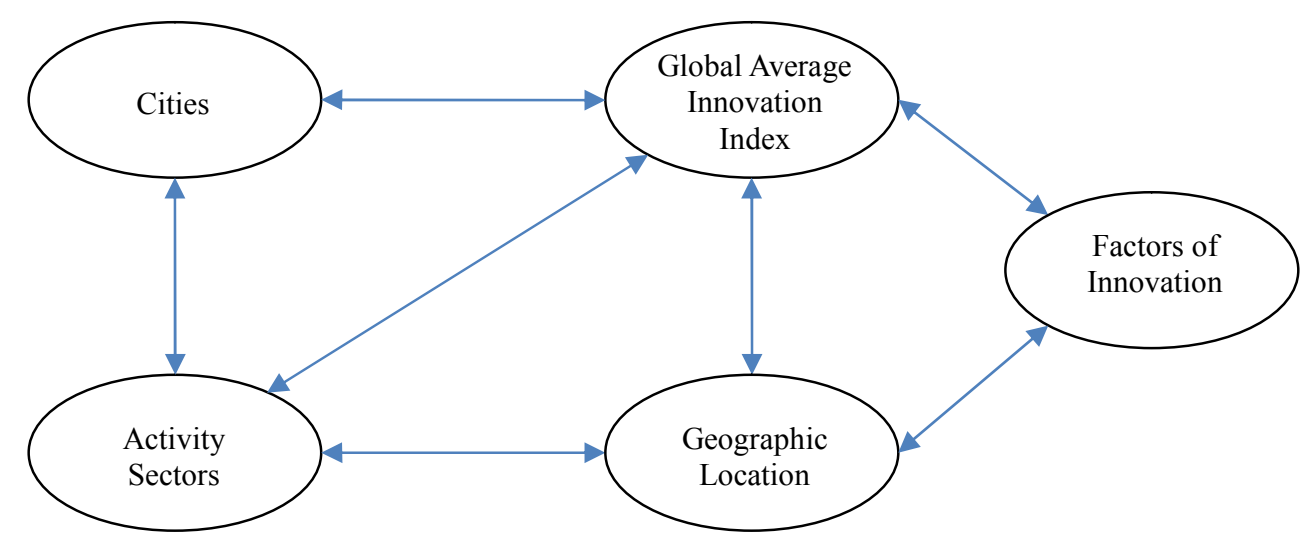

Figure 1. Conceptual model.

The justification of the model is based on Skibinski and Sipa (2015). They claimed that MSEs should make use of external knowledge sources as they have limited internal resources. In this way, the ability to exploit and use the knowledge that comes from abroad becomes a key element and predictor of successful innovation, which makes the environment in which they are located really important to innovation. The general and classic models of innovation presented by Rothwell (1994) define innovation as a set of processes that should be undertaken by the organizations in isolation for the development of innovations, especially in the development of new products. Recent models of innovation such as Cooper (1988), Khurana and Rosenthal (1997), Koen, Ajamian, Burkart, Clamen, Davidson, D'amore, ..., and Wagner (2001), Flynn, Dooley, O'sullivan, and Cormican (2003), Boeddrich (2004), Reid and Brentani (2004), Whitney (2007), Brem and Voigt (2009) and Kurkkio, Frishammar, and Lichtenthaler (2011), besides being strictly theoretical, focused on large companies and on processes that companies must undertake in isolation. They also emphasized the development of products to the detriment of the development of other types of innovation, such as services, processes, marketing and organizational. The theoretical model presented in this paper differs from the models listed by: (1) being a model that seeks to investigate how the degree of innovation is configured to the detriment of the business environment, having a more comprehensive perspective than the company object alone, as is the case with the abovementioned models; (2) to characterize itself as a suitable model for the investigation of innovation in MSEs by presenting a system of interactions between MSEs and their business environments, thus enabling the investigation of the degree of innovation according to location geographical; and (3) to provide information on MSEs innovation in a global way, not limited solely to the development of products.

\section{Objective of Study and Research Hypotheses}

The main objective of this research was to present a research model of innovation in MSEs to analyze: (1) the degree of innovation of MSEs; and (2) how the innovation is presented in MSEs as a result of its business environments.

Accordingly, with the main objective of testing the conceptual model presented in Figure 1, the following research hypotheses are established:

$\mathrm{H}_{1}$ : The MSEs of the State of Piauí present little innovative. 
The conceptual framework of $\mathrm{H}_{1}$ is based on Demonel and Marx (2015), Reichert et al. (2015), and Taborda et al. (2013), because they said that innovation in MSEs entails greater difficulties related to lack of resources, scarce or nonexistent investments in $\mathrm{R} \& \mathrm{D}$, strong dependence on technology acquisition (machinery and equipment) and limited managerial capacities. Nevertheless, in developing countries (DC), as Rojas and Carrillo (2014) pointed out, market failures such as imperfect competition, externalities and information asymmetries have a negative impact on companies' capacity for innovation, which they assume defensive and merely reactive strategies:

$\mathrm{H}_{2}$ : Innovation in MSEs in the State of Piauí presents itself differently due to its business environments (geographical location and sectors of activity).

$\mathrm{H}_{2.1}$ : The Global Average Innovation Index is different for cities.

$\mathrm{H}_{2.2}$ : The Global Average Innovation Index is different for the activity segments.

$\mathrm{H}_{2.3}$ : The Global Average Innovation Index is different for geographic location.

The conceptual framework of $\mathrm{H}_{2}$ is based on Aarstad, Kvitastein, and Jakobsen (2016), since they pointed to the geographic environment as an important factor influencing growth, profits, and business development, including survival and innovation performance. In this sense, as established by Skibinski and Sipa (2015), innovation in MSE may be associated with its ability to explore and use the knowledge that comes from its environment.

\section{Data Analysis}

The instrument used for data collection was a questionnaire survey. The instrument is composed of 32 items that evaluate 13 dimensions of the innovation, resulting from an adaptation made by Bachmann (2011) for application in MSEs of the Innovation Radar, of Sawhney, Wolcott, and Arroniz (2006), originally constituted of 12 dimensions. The innovation dimensions assessed by the Innovation Radar are: (1) supply; (2) platform; (3) brand; (4) customers; (5) solutions; (6) relationship; (7) value aggregation; (8) processes; (9) organization; (10) supply chain; (11) presence; (12) network; and (13) innovative ambience.

The study was conducted with a sample of 550 MSEs of the State of Piauí, Brazil, during the months from October 2014 to October 2015. For the treatment, analysis and interpretation of the data were used the software SPSS Statistics in its Version 22 and Numbers in its Version 3.1. The statistical techniques used were descriptive, exploratory and inferential in order to describe, analyse and interpret the behaviour of the attributes under study. Thus, in the first phase, we chose to calculate the Global Average Innovation Index (GAII), obtained by means of the simple arithmetic mean of the above mentioned 13 dimensions of Innovation Radar (see Equation (1)):

$$
G A I I=\frac{1}{n} \sum_{i=1}^{n} X_{i}
$$

where $n$ corresponds to the number of independent variables of the Innovation Radar; $X_{i}$ corresponds to the independent variables of the Innovation $\operatorname{Radar}(i=1, \ldots, 13)$.

$$
G A I I=\frac{1}{13} \sum_{i=1}^{13} X_{i}
$$

where $X_{1}$, supply; $X_{2}$, platform; $X_{3}$, brand; $X_{4}$, customers; $X_{5}$, solutions; $X_{6}$, relationship; $X_{7}$, value aggregation; $X_{8}$, processes; $X_{9}$, organization; $X_{10}$, supply chain; $X_{11}$, presence; $X_{12}$, network; and $X_{13}$, innovative environment. 
A sample error of $4.17 \%$ and a significance level of $5 \%$ were used to calculate the sample size. In order to make the decisions regarding the different hypotheses of investigation, a level of significance of $5 \%$ was assumed throughout the analysis.

\section{Analysis and Presentation of Results}

The study sample consists of 550 MSEs distributed among six cities in the State of Piauí, as follows: Teresina 371 (67.5\%); Bom Jesus 46 (8.4\%); Floriano 39 (7.1\%); Piripiri 32 (5.8\%); Picos 30 (5.5\%) and Parnaíba 32 (5.8\%). Regarding the distribution of MSEs by activity sectors, it is estimated that $61.3 \%$ and $38.7 \%$ represent the services and commerce segments, respectively. Regarding the location, $67.5 \%$ of the MSEs in the sample are located in the state capital, while $32.5 \%$ are located in the interior of the State. In order to answer the first research hypothesis, the GAII was calculated by means of the simple arithmetic mean of the 13 dimensions of the Innovation Radar, whose overall mean value was 2.00 points (deviation standard of 0.92), denoting globally that the MSEs of the study sample have innovation capacity between "little innovative" and "occasional innovative", according to the adapted classification of Neto and Teixeira (2011), in which the final average score of 1 means "little innovative", the final average score of 3 means "occasional innovative" and the final average score of 5 means "systemic innovative". The mean standard deviation of 0.92 indicates that the firms analysed responded to questions related to the Innovation Radar in the same sense, that is, there was little variability around them.

Since the MSEs of the sample have a GAII of 2.00 points (standard deviation of 0.92 ), indicating that they are between "little innovative" and "occasional innovative", responding to research hypothesis 1 , we intend to verify if there are differences in the GAII average for cities, geographic location and activity sectors to answer the research hypothesis 2 .

The verification of the existence of differences in the GAII average for the cities is done through the application of one-way ANOVA. In order to be a parametric test, some assumptions need to be validated, namely, if the variables follow the normal distribution in the different independent groups (using the Kolmogorov-Smirnov test), homogeneity of variances (Levene test), and independency between groups, assuming a significance level of 5\%. Considering the normality test, Kolmogorov-Smirnov test, it was concluded that at a significance level of $5 \%$, there is enough statistical evidence to state that the study variable does not follow a normal distribution in the independent groups under study.

Given the violation of the first assumption for the application of the parametric test, the non-parametric alternative, in the case in question, was immediately applied to the Kruskal-Wallis test, in order to compare the GAII distributions in the six cities (independent groups).

Using the Kruskal-Wallis test, considering that the obtained value was 0.394 , it can be concluded that there is no statistical evidence at the significance level of $5 \%$ to state that at least one of the GAII distributions is different for the six cities.

In order to verify if there are differences in the GAII mean for the geographic location, the $t$-student parametric test was used for two independent samples, whose application assumptions are normal population or $n \geq 30$ observations and unknown standard deviation. 
However, once the sample size is different in both groups, the Levene test was applied to verify if the variances were homogeneous assuming a significance level of 5\%. From the results obtained, it is concluded that there is not enough statistical evidence to affirm that the variances are significantly different at a level of significance of $5 \%$, since the obtained value was 0.310 , higher than the level of significance assumed. In relation to the $t$-student, considering that the test value is 0.704 , higher than the level of significance assumed, it is concluded that there is enough statistical evidence to affirm that the average GAII is equal to the MSE of the interior and the capital to a level of significance of $5 \%$.

In order to verify if there are differences in GAII mean for the activity sectors variable, the $t$-student parametric test is applied once again for two independent samples, which as referred to has normal or $n \geq 30$ and normal deviation and unknown standard. However, given the differences in sample size for both groups, the Levene test was applied to verify if the variances were homogeneous assuming a significance level of $5 \%$. It is concluded that there is not enough statistical evidence to state that the variances are significantly different at a significance level of $5 \%$, since the obtained value was 0.144 , higher than the level of significance assumed. In relation to the $t$-student, considering that the test value is 0.992 , higher than the level of significance assumed, it is concluded that there is enough statistical evidence to state that the mean GAII is equal to the MSE of the segments of commerce and services at a significance level of $5 \%$.

Based on what has been presented previously, it is concluded that the research hypotheses have not been validated, that is, since the GAII obtained through the average of the 13 dimensions of the Innovation Radar applied in the 550 MSEs of the State of Piauí was 2.00 (standard deviation of 0.92), the MSEs of the sample under study had an innovative capacity between "little innovative" and "occasional innovative", resulting in a non-validated research hypothesis 1 . However, because the GAII distribution is the same among cities, the GAII average is the same between the sectors of activity and for the geographical location, the research hypothesis 2 is not valid since there is sufficient statistical evidence to affirm that the innovation presents itself homogenized for the MSE of the study, using the control variables city, activity sectors and geographic location.

Šoltés and Gavurová (2014) argued that the effective development of innovation requires a functional innovation system composed of institutions, policies and tools to create conditions that promote innovation. After all the inferential analysis carried out, contrary to the literature on the subject (e.g., Demonel \& Marx, 2015; Taborda et al., 2013) that present MSE as not very innovative, it is possible to state that there are indications that the functional innovation system that promotes the innovation of MSEs is to a certain extent present in the State of Piauí, although in an incipient form, since MSEs have innovation capacity between "little innovative" and "occasional innovative", leaving room for fundamental improvements in the degree of innovation, and that this capacity is homogenized for the MSEs of the study.

\section{Conclusion}

As mentioned above, the main objective of the present investigation was to verify how the innovation presents itself in the MSEs of the State of Piauí, so that the following hypotheses of investigation were established:

$\mathrm{H}_{1}$ : The MSEs of the State of Piauí present themselves as little innovative.

$\mathrm{H}_{2}$ : Innovation in MSEs in the State of Piauí presents itself differently due to its business environments (geographical location and sectors of activity). 
Overall, the MSEs of the sample under study have innovation capacity between "little innovative" and "occasional innovative", since the Global Average Innovation Index (GAII) obtained through the average of the 13 dimensions of the applied Innovation Radar in the 550 MSEs of the State of Piauí was 2.00 (standard deviation of 0.92). Since the classification usually adopted establishes that the final average score of 1 means "little innovative", the final average score of 3 means "occasional innovative" and the final average score of 5 means "systemic innovative", it can be affirmed that the MSEs of the sample under study have innovative capacity between "little innovative" and "occasional innovative", resulting in a non-validated the research hypothesis 1.

In order to verify in a general way how the GAII of the MSEs presents as a result of the control variables city, activity sectors, and geographic location, using inferential analyzes, it was observed that the distribution of GAII is the same between cities and that the GAII average is the same between activity sectors and geographic location. Because the distribution of GAII is the same among cities; of the innovation average is the same among the MSEs of the commerce and services segments, as well as between the MSEs in the interior and the capital, the second research hypothesis is also not validated, since there is enough statistical evidence to affirm that innovation is homogenized for the MSEs of the study, using the control variables city, activity sectors and geographic location.

The results obtained provide an important practical contribution to the management and monitoring of innovation in MSEs in a given region by presenting an indicator that reflects how much innovation is present, serving as a parameter for potential improvements by both companies and the public power. As theoretical contributions, the presented model leads to useful and systematic information on how innovation presents itself in MSEs in a global way as a result of its business environments, and can thus be useful as a model that serves as a parameter for the improvement of innovation through public policies aimed at improving the business environment that increase the degree of innovation of the companies that constitute it, and therefore validate the theoretical model in the case in question. Possible public policies are the establishment of partnerships with universities and local research institutes, with a view to obtaining the necessary resources for innovation, the formation of innovation networks between MSEs and financial subsidies by the government for companies that join the innovation networks.

The limitations of the study are the unavailability of information on the number of employees, turnover, investments in R\&D and training efforts, which would be useful for more detailed analyses of the innovation capacity of the companies studied. In addition, although the theoretical model presents useful information of the global form as the innovation presents itself, it does not make it possible to identify in detail the types of innovation developed by the companies studied, considering the innovation as a homogeneous whole within a given business environment.

As future research, we intend to develop studies that identify the factors that serve as obstacles or that facilitate innovation in MSEs, the relationship between innovation and economic development, and how the quality of human resources influences MSE innovation capacity.

\section{References}

Aarstad, J., Kvitastein, O., \& Jakobsen, S. (2016). Related and unrelated variety as regional drivers of enterprise productivity and innovation: A multilevel study. Research Policy, 45, 844-856.

Apak, S., \& Atay, E. (2014). Global innovation and knowledge management practice in small and medium enterprises (SMEs) in Turkey and the Balkans. Procedia - Social and Behavioral Sciences, 150, 1260-1266. 
Bachmann, D. L. (2011). Metodologia para determinar o radar da inovação nas pequenas empresas. Curitiba: (s.n.).

Bayarçelik, E., Tasel, F., \& Apak, S. (2014). A research on determining innovation factors for SMEs. Procedia - Social and Behavioral Sciences, 150, 202-211.

Boeddrich, H. J. (2004). Ideas in the workplace: A new approach towards organizing the fuzzy front end of the innovation process. Creativity \& Innovation Management, 13(4), 274-285.

Brem, A., \& Voigt, K. I. (2009). Integration of market pull and technology push in the corporate front end and innovation management-insights from the German software industry. Technovation, 29(5), 351-367.

Cooper, R. G. (1988). The new product process: A decision guide for management. Journal of Marketing Management, 3(3), 238-255.

Demonel, W., \& Marx, R. (2015). Gestão da Cadeia de Valor da Inovação em ambientes de baixa intensidade tecnológica. Production, 25(4), 988-999.

Drucker, P. (1987). Inovação e Gestão: uma nova concepção de estratégia de empresa. Lisboa: Editorial Presença.

Flynn, M., Dooley, L., O’sullivan, D., \& Cormican, K. (2003). Idea management for organisational innovation. International Journal of Innovation Management, 7(4), 417-442.

Gupta, S., Malhotra, N., Czinkota, M., \& Foroudi, P. (2016). Marketing innovation: A consequence of competitiveness. Journal of Business Research, 69, 5671-5681.

Hamdani, J., \& Wirawan, C. (2012). Open innovation implementation to sustain Indonesian SMEs. Economics and Finance, 4, 223-233.

Khurana, A., \& Rosenthal, S. R. (1997). Integrating the fuzzy front end of new product development. Sloan Management Review, 38(2), 103-120.

Koen, P. A., Ajamian, G., Burkart, R., Clamen, A., Davidson, J., D’amore, R., ..., \& Wagner, K. (2001). Providing clarity and a common language to the "fuzzy front end". Research Technology Management, 44(2), 46-55.

Kurkkio, M., Frishammar, J., \& Lichtenthaler, U. (2011). Where process development begins: A multiple case study of front end activities in process firms. Technovation, 31(9), 490-504.

Martín, L. A., \& López, J. M. (2007). La Dirección Estratégica de la Empresa: teoria y aplicaciones. Pamplona: Editorial Aranzadi.

Molano, C., \& Campo, J. (2014). Gerencia estratégica e innovación empresarial: referentes conceptuales. Revista Dimensión Empresarial, 12(1), 107-116.

Neto, A., \& Teixeira, R. (2011). Mensuração do Grau de Inovação de Micro e Pequenas Empresas: Estudo em Empresas da Cadeia Têxtil-Confecção em Sergipe. XXXV ENANPAD, Rio de Janeiro, Setembro.

OCDE \& FINEP. (2005). Manual de Oslo (3.ed.). Rretrieved from http://www.mct.gov.br/upd_blob/0011/11696.pdf

Paula, C. (2014). Análise do grau de inovação das Micro e Pequenas Empresas do segmento alimentício atendidas pelo programa Agentes Locais de Inovação na Região Oeste do Estado de Goiás (Dissertação de Mestrado, Faculdades Alves Faria, Goiânia, GO, Brasil).

Pereira, M., Grapeggia, M., Emmendoerfer, M., \& Três, D. (2009). Fatores de inovação para a sobrevivência das Micro e Pequenas Empresas no Brasil. RAI - Revista de Administração e Inovação, 6(1), 50-65.

Reichert, F., Camboim, G., \& Zawislak, P. (2015). Capacidades e Trajetórias de Inovação de Empresas Brasileiras. Ram-Revista de Administração Mackenzie, 16(5), 161-194.

Reid, S. E., \& Brentani, U. (2004). The fuzzy front end of new product development for discontinuous innovations: A theoretical model. Journal of Product Innovation Management, 21(3), 170-184.

Rodrigues, A. (2003). Cluster e Competitividade: um estudo da concentração de Micro e Pequenas Empresas de Alimentos no município de Marília/SP (Tese de Doutoramento, Universidade de São Paulo, São Carlos, SP, Brasil).

Rojas, S., \& Carrillo, A. (2014). Sistema para la evaluación de capacidades de innovación en pymes de países en desarrollo: caso Panamá. Revista Facultad de Ciencias Económicas, 22(2), 109-122.

Rothwell, R. (1994). Towards the fifth generation innovation process. International Marketing Review, 11, 7-31.

Rovere, R. L. (2001). Perspectivas das Micro, Pequenas e Médias Empresas no Brasil. Revista de Economia Contemporânea, 5 , 20-38.

Rusu, B. (2016). The impact of innovations on the business model: Exploratory analysis of a small travel agency. Procedia Social and Behavioral Sciences, 221, 66-175.

Sawhney, M., Wolcott, R. C., \& Arroniz, I. (2006). The 12 different ways for companies to innovate. MIT, Spring. 
Schumpeter, J. A. (1997). Teoria do Desenvolvimento Económico: uma investigação sobre lucros, capital, crédito, juro e o ciclo económico. São Paulo: Editora Nova Cultura.

Seo, Y., \& Chae, S. (2016). Market dynamics and innovation management on performance in SMEs: Multi-agent simulation approach. Computer Science, 91, 707-714.

Skibinski, A., \& Sipa, M. (2015). Sources of innovation of small businesses: Polish perspective. Economics and Finance, 27, 429-437.

Šoltés, V., \& Gavurová, B. (2014). Innovation policy as the main accelerator of increasing the competitiveness of small and medium-sized enterprises in Slovakia. Economics and Finance, 15, 1478-1485.

Taborda, C., Estevão, C., \& Nunes, S. (2013). A gestão da inovação nas PME's da Beira Interior: as perspetivas dos gestores. Tourism \& Management Studies, 9(2), 124-129.

Tidd, J., Bessant, J., \& Pavitt, K. (2008). Gestão da Inovação (3.ed.). Porto Alegre: Bookman.

Titu, A., Raulea, A. S., \& Titu, S. (2015). Innovation - A challenge for the 21 st century managers. Economics and Finance, 27, 126-135.

Toivonen, T. (2015). Continuous innovation - Combining Toyota Kata and TRIZ for sustained innovation. Engineering, 131, 963-974.

Whitney, D. E. (2007). Assemble a technology development toolkit. Research Technology Management, 50(5), 52-58. 